\title{
Role-Play Simulation for Assessing Students' Creative Skill and Concept Mastery
}

\author{
Nisrina Meta Gamanik,1,3*, Yayan Sanjaya², Lilit Rusyati1 \\ ${ }^{1}$ International Program on Science Education, Faculty of Mathematics and Science Education, Universitas Pendidikan Indonesia, \\ Bandung, Indonesia \\ 2Department of Biology Education, Faculty of Mathematics and Science Education, Universitas Pendidikan Indonesia, Bandung, \\ Indonesia \\ ${ }^{3}$ SMP Islam Cendekia Cianjur, Cianjur, Indonesia
}

*Corresponding Author. lilitrusyati@upi.edu

\begin{abstract}
This study treats students by role-play simulation for learning the human circulatory system. Creative skill and concept mastery to be assessed aspects at the end of learning. The method used in this research is the quasi-experimental method. The sample was taken by cluster random sampling technique with the population of students in 8th grade at one of Junior High School in Bandung. The samples in the experimental class $n=24$ and control class $n=24$.the data obtained using the rubric of creative skill consist of process and product. For treatment in experiment class, implemented the role play while for the control class conducted the group discussion. This study aims to examine the effect of role-playing on students' concept mastery and creative skills. The data result of students' concept mastery was taken by pretest and posttest. The result of students' concept mastery was indicated by mean of posttest score in the experimental class, which is implemented the role play is higher than the control class, $79.50>64.00$, respectively. Creative skills in the process that will be seen during the implementation of the role play and creative skills in product measured by the scenario of the role play. This research indicated that role play could be implemented in the teaching-learning process. The research findings show that there is a significant effect of role-playing on students' concept mastery and lead students to be skillfully creative.
\end{abstract}

Keywords Roleplay, Concept mastery, Creative skills, Human circulatory system

\section{INTRODUCTION}

Teaching and learning process should be raised by students engagement. Especially in science learning, the student has the probability of taking all procedures to be a scientist. Role-play simulation be student engagement tools for enhancing learning effectiveness, collaborative capacity, and facilitating social learning (Rumore, Schenk, \& Susskind, 2016). Although role-play simulation has given benefit for students, the teacher also should consider how format and preparation for teaching (Stevens, 2015).

Many of Indonesian students have been found a lack of interest in the lesson on their school during the learning activity, and it is influencing their ability to mastery the concept (Azra, 2002). This has been observed by Bjork (2005) and ascribed to the long tradition of the way of teaching-learning and rote learning in the Indonesian Classroom. In our modern society, science and technology play central role various method for education or education method were developed for teaching science in a school to create scientific knowledge, understanding of the impacts to society and its underlying social process (Önkal, Sayım, \& Lawrence, 2012). Role-play simulation is one of the methods for teaching science, which is unique, new, and revolutionary. Besides that, there are rarely researchers focused on the scope of role-playing which is used by real people in a real situation (Daniau, 2016).

Teaching method, which is used in Indonesia, commonly are not varieties and tends to be teachercentered. It makes students less interested, feel bored, and do not engage in the teaching-learning process that is why students consider human circulatory as a difficult subject. Students have difficulties in imagining biology phenomena in real life, so they remember the aspects without knowing what is happen there. Students tend to be passive and listen

Received: 11 January 2019

Revised: 18 May 2019

Published: 22 July 2019 
to what their teacher explains. Students' attitude toward biology lesson should not be that passive, and students should be more active since attitudes are integrally linked to learning achievement (Freire, Baptista, \& Freire, 2016). Roleplay activities can develop students' visualization through a range of modalities, which included embodied sensation and andromorphic metaphors. The essence of science role play at school is to shape a contextualization for science and technology to trigger imagination, raise questions and stimulate debate among students to increase the science concept mastery (Prima, Putri, \& Sudargo, 2017).

Drama typed activities such a role play can support the learning of cognitive, affective and technical objective especially higher-order thinking skills related to analysis, synthesis and evaluation and it has been claimed (Anderson, 2001). Roleplay can enable meaningful learning, and it is already suggested by experimental studies. A central characteristic of these activities is that they are seen to promote opportunities for "interactive dialogue," dialogic teaching (Edmiston, \& Wilhem, 1998), and students centered discourse (McSharry \& Jones, 2000). Furthermore, the literature consistently highlights findings of high motivation among students, imbued in part of their perception of empowerment and ownership during these events (Prima, Putri, \& Rustaman, 2018).

Although role-play simulation was proved to be successful, there is a possibility that students personally do not to be able to grasp the material maximally through this method since each student has their characteristic and because of they are uniquely different attitude and characteristics toward role play. Some of the students are well to learn by role-play method, and some of them are not. One of the students' learning characteristics is students' multiple intelligence. Based on various intelligence theory written by Yasin, Prima, \& Sholihin (2018), identifying each student's information has substantial ramifications in the classroom. If a child's intelligence can be defined, then teachers can accommodate different children more successfully according to their orientation to learning. Teachers in the traditional classroom primarily teach verbal/linguistic and mathematical/logical intelligence. It has been claimed that drama or drama typed activities such as role-plays, can support learning cognitive, affective and technical objective, especially higher-order thinking skills related to analysis, synthesis, and evaluation (McSharry, \& Jones, 2000).

\section{METHOD}

The research method used in this study is the Quasi Experiment. This is related to the research, which is to investigate the effectiveness of role-playing on students' concept mastery and students' creative skills in learning the human circulatory system. Creswell (2012) stated that

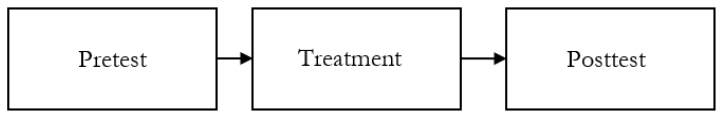

Figure 1 Design illustration of one group pretest-posttest

quasi-experiment include assignment, but not the random assignment of participant groups. This is because the experiment cannot artificially create a group for the test. The quasi-experiment provides research with the opportunity to assess the effects of interventions or treatments. By applying this method, there was two groups which are experiment and control class.

This research finds students to be tested. Then the researcher introduces a role play that should change the people and test to see if there were any changes. The pretest post-test that would be taken in this research as following steps (a) Test the students' prior knowledge regarding of circulatory system as the topic (b) Perform the experimental through role play (3) Test the students after the role-play completed to be done as the post-test to see the changes in students' concept mastery and creative thinking. The research design was used in this research is one group pretest and posttest design (Figure 1).

This research is conducted in one of school in Bandung, which applied Kurikulum 2013 in the teaching and learning process. The data collection was done in May 2018. Based on Anderson and Krathwohl (2001) stated that population is a set or collection of an element processing one or more attributes of interest all subject in research. The data population was conducted from all students' school in 8th grade in investigating the teaching-learning process in the classroom. The sample of this research is one of 8th-grade class in one of junior high school in Bandung that applying Kurikulum 2013 using cluster technique sampling. Cluster random sampling is determining sample randomly, which give a better probability for this research.

The population in this research was an 8th-grade student at Junior High School is one of the Bandung School years 2017/2018. After observation, the taken sample was 8th-grade students from two different classes in Junior High School " $\mathrm{X}$ " Bandung. The researcher researched in the $8 \mathrm{~B}$ Class, which learn the topic about a human circulatory system by implementing of role play as a learning method for the experiment class. Another class for compare is the $8 \mathrm{C}$ as the control class, which learn the same topic by implementing of the joint project, group discussion and communicate the result in front of the course as the task for students.

\section{RESULT AND DISCUSSION}

\subsection{Role Play}

The role play implementation data is obtained by the observation sheet, which was written by two observers in both the first and second meeting. Since the teachinglearning process is two-way action from teacher and 
Table 1 Classroom activity data

\begin{tabular}{llll}
\hline No. & Dimension & 1st Meeting $^{\text {st }}$ & $\begin{array}{l}\text { 2nd } \\
\text { Meeting }\end{array}$ \\
\hline 1 & Opening Activity & $100 \%$ & $100 \%$ \\
2. Core Activity & $100 \%$ & $100 \%$ \\
$3 . \quad$ Closing Activity & $80 \%$ & $100 \%$ \\
Average & $93 \%$ & $100 \%$ \\
\hline
\end{tabular}

students. Thus, in this research, is observation sheet for the classroom activity rubric. This activity rubric is a concern on classroom activity that is done in the classroom. This rubric will show the action whether it is according to the lesson plan or not. The largest the percentage the more representative is the activity. The rubric is divided into three main dimensions. Those are opening, core, and closing activity. Each aspect has different events, from opening the class, gaining students' attention, teaching the material until closing the lesson. The result of the calculation can be seen in Table 1 .

Based on the table above, it could be seen over all the score is relatively high, so it means that the activity is quite representative based on the lesson plan. It shows that the first meeting, the opening as well as score activity, was conducted according to what the researcher planned on the lesson plan.

Therefore, for the closing activity was only $80 \%$ because the researcher should divide the allocation time with the implementation role play by doing the drama based on the scenario of human circulatory system made by themselves, while the researcher was observing their expressions and their activity according to the creative skills rubric to determine the level of their creative skills. After they have done with the role-play, the researcher was giving more time to discuss what they had learned during the whole activity by the question and answer session doing by teacher and students, also conclude the lesson for the human circulatory system. After the discussion session was done, they were doing the posttest given by the researcher to measure how far they mastery the concept by implementing the role play.

\subsection{Students' Concept Mastery}

The instrument that used to measure students concept mastery is objective tests in the form of 25 multiple choice questions as pretest and posttest in the topic of learning the human circulatory system by implementing the role play. The data was collected by 24 participants of students in each class. The parameter that is used was revised of Bloom's cognitive domain. The item tests are based on the indicator of the learning process.

Item test has been tested in term of validity, reliability discriminating power, distractor, and difficulty level. Item test also judged by some experts, then revised. Therefore, it is adequate to be used as a research instrument to get data about students' concept mastery. The item tests measured by cognitive level domain based on Taxonomy Bloom used
Table 2 Recapitulation of students' pretest and posttest based on cognitive level domain

\begin{tabular}{llll}
\hline Class & Data & \multicolumn{2}{l}{ Cognitive Level } \\
\multirow{3}{*}{ Experiment } & & $\mathrm{C} 1$ & $\mathrm{C} 2$ \\
\cline { 2 - 4 } & & 40.48 & 17.26 \\
& Pretest (\%) & 80.35 & 77.40 \\
& Posttest (\%) & 39.87 & 60.14 \\
& Gain (\%) & 0.7 & 0.7 \\
& $<\mathrm{g}>$ & High & High \\
Control & Category & 38.09 & 27.98 \\
& Pretest (\%) & 73.80 & 50.60 \\
& Posttest (\%) & 35.71 & 22.62 \\
& Gain (\%) & 0.6 & 0.3 \\
& $<$ g> & Medium & Medium \\
\hline
\end{tabular}

the questions level C1-C6. C1 -C5 are shown by multiplechoice, and C6 level is determined by instruction in project design sheet for students make a scene as the product.

Based on objective tests before that had given both in experiment and control class, there is the following table shows the result of students' concept mastery in learning human circulatory system based on the cognitive level domain (Table 2).

Based on Table 2, the data are influenced by score pretest and posttest in each category of the cognitive domain. Thus, the experiment class could give a significant effect compared to the control one. Discrimination of item test domain incudes the validity, reliability, discriminating power, difficulty level, and distraction of item test. The researcher also considered the result of judgment that is judged by some expert.

Based on Table 2, it clearly can be seen that there is a significant effect in all of the cognitive domain, the scores are increasing, which get $\mathrm{C} 5$ level in both of class. It can be analyzed that $\mathrm{C} 5$ is the highest level in item test in the form of objective analysis given by the teacher to the students. Based on Bloom's taxonomy, this question includes higherorder thinking skill to evaluate categories that must be able to check and critiquing ability. The data collected from the

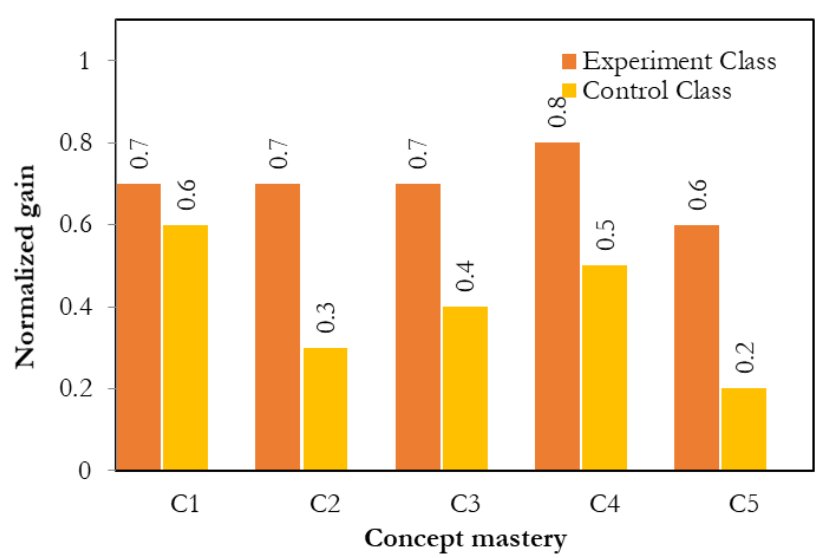

Figure 2 Students' concept mastery based on the normalized gain score in experiment 
Table 3 Result of the pretest and posttest score based on the structural result in experiment and control class

\begin{tabular}{llll}
\hline Test & Score & $\begin{array}{l}\text { Experiment } \\
\text { Class }\end{array}$ & $\begin{array}{l}\text { Control } \\
\text { Class }\end{array}$ \\
\hline Pretest & Highest & 40 & 60 \\
& Lowest & 16 & 16 \\
& Mean & 32.17 & 38.67 \\
& Standard & 5.96 & 12.41 \\
& Deviation & & \\
Posttest & Highest & 96 & 88 \\
& Lowest & 44 & 44 \\
& Mean & 79.50 & 64.00 \\
& Standard & 11.99 & 13.71 \\
Gain & Deviation & & \\
N-Gain & & 47.17 & 24.34 \\
Criteria & & 0.7 & 0.4 \\
\hline
\end{tabular}

result pf pretest and posttest score. The comparison in the experiment class and control class can be seen in Figure 2.

The result got from $<\mathrm{g}>$ in each cognitive level (C1-C5) in both experiment and control class. It clearly can be seen that in the experiment class, the students' concept mastery is higher than the control one. From the data shown that in level $\mathrm{C} 5$ get the lowest score form both types. There are six cognitive domains stated (C1-C6), but there is no C6 included in the objective test. The $\mathrm{C} 6$ is investigated in the form of a project sheet that contains students to create an analogy about the topic through the scenario of role play. In the experiment class, the teacher only gives the students instruction to make a scenario according to the issue after the teacher explaining or giving the outline of the human circulatory system topic. Therefore, for the control class, the teacher provides instruction to them gaining the information about the human circulatory system based on textbook and internet and discuss it in pairs before communicating it in front of the class.

Based on Table 3, it can be seen for both classes experienced an increasing score, thus that the students generally experienced the effect of mastery the concept. The highest score in experiment class on pretest is 40, and the lowest score is 16 meanwhile in posttest the highest score is 60 , and the lowest score is 16 . The posttest result shows that the highest score is 88 and the lowest is 44 . The effect of students' concept mastery determined by calculating the score of normalized gain or $\langle\mathrm{g}\rangle$. The calculating of this score using formula and get the data in experiment class $<\mathrm{g}>$ is 0.7 that categorize as high and in control class $<\mathrm{g}>$ is 0.4 that categorize as the medium.

Based on the data can be seen the range of mean in experiment class on pretest is 32.17 and posttest shown the score is 79.50 while in control class the pretest is 38.67 and posttest is shown the score is 64.00 . Those are taught that in the pretest of experiment class lower than the control class but the posttest, the experiment class is higher than the control class. From the result of calculation statically, the difference between the pretest and the posttest is stated
Table 4 Result of normality test on students' concept mastery

\begin{tabular}{lllll}
\hline Components & $\begin{array}{l}\text { Pretest } \\
\text { Experiment } \\
\text { Class }\end{array}$ & $\begin{array}{l}\text { Control } \\
\text { Class }\end{array}$ & $\begin{array}{l}\text { Posttest } \\
\text { Experiment } \\
\text { Class }\end{array}$ & $\begin{array}{l}\text { Control } \\
\text { Class }\end{array}$ \\
\hline $\begin{array}{l}\text { Sig } \\
\text { Normality }\end{array}$ & 0.131 & 0.200 & 0.200 & 0.133 \\
$\begin{array}{l}\text { Test } \\
\text { Kolmogorov- }\end{array}$ & & Sig. $\geq 0.05=$ Normal \\
$\begin{array}{l}\text { Smirnov } \\
\text { Conclusion }\end{array}$ & Normal & Normal & Normal & Normal \\
\hline
\end{tabular}

Table 5 Result of homogeneity test on students' concept mastery

\begin{tabular}{|c|c|c|c|}
\hline \multirow[t]{2}{*}{ Components } & Experiment Class & \multicolumn{2}{|c|}{ Control Class } \\
\hline & Pretest Posttest & Pretest & Posttest \\
\hline Sig. & \\
\hline Lavene's & \multirow{3}{*}{\multicolumn{3}{|c|}{ Sig $\geq 0.05=$ Homogenic }} \\
\hline Homogeneity & & & \\
\hline Test & & & \\
\hline Conclusion & Homogenic & \multicolumn{2}{|c|}{ Homogenic } \\
\hline
\end{tabular}

$\underline{\text { Table } 6 \text { Result of hypothesis test on students' concept mastery }}$

\begin{tabular}{llll}
\hline \multirow{2}{*}{ Components } & \multicolumn{2}{l}{ Experiment Class } & \multicolumn{2}{l}{ Control Class } \\
& Pretest Posttest & Pretest & Posttest \\
\hline Sig. & 0.000 & \\
Independent & Sig $(2$-tailed $) \leq 0.05, \mathrm{H}_{\mathrm{O}}=$ Rejected & \\
T-Test & & \\
Conclusion & $\mathrm{H}_{\mathrm{o}}$ Rejected, $\mathrm{H}_{1 \text { Retained }}$ & \\
\hline
\end{tabular}

by gain score $(G)$ as much as 47.17 in experiment class and 24.34 in the control class. Means that the effect of students' concept mastery in experiment class is better than the control class shown by the increasing score.

Based on the pretest and posttest score, learning process that applied in class also affects the level of students' concept mastery, this is in line with the statement from Newman and Flaherty (2012) when checked all students' levels of concept mastery through each lesson it sets tine that everyone's thinking is essential and necessary and it can forward the learning and engagement of all. Some techniques are time-consuming to use as quick pulse checks, but use this essential technique together in all lessons allow tracking learning and adapting instruction appropriately on the spot. Teacher use guided practice to enhance their understanding and, in this research, implementing the role play that guided practice for students those stages are planning, creating, evaluating that implemented in lesson plan (Daniau, 2016).

Implementation of role-playing in the learning process improves the students' understanding based on Önkal, Sayım, \& Lawrence (2012) state that role play is an effective way to involving students in active social studies learning. Roleplay for learning human circulatory system also analogically describe what's happening in the human's body and human's heart.

The statistical data of pretest and posttest in experiment class and control class calculated to determine whether the normality, homogeneity, the hypothesis is accepted or 
rejected. All test using the statistical measurement was conducted. The result is shown in Table 4.

Based on the result of normality test use Kolmogorov Smirnov through the pretest score in experiment class the sig value is 0.131 and control class is 0.200 while through posttest score is normal distribution in experiment class and control class where sig. $\geq 0.05$. So that the data continued to homogeneity test using One Way ANOVA (Table 5).

The homogeneity test called Lavene's test to know that the data has the same variants or not with the rules if the sig. Value $\leq 0.05$ shows that the data has the same options (homogenous). This measurement uses the gain score of experiment class and control class. The gain score gets from the result of pretest and posttest score in both of course. Due to all of the data shown the normal and homogeneity so that the hypothesis test is conducted by using parametric T-test (Table 6).

In this research, the hypothesis relation with the students' concept mastery in both of class that is already implementing the role play and group discussing. The study has an independent variable and a dependent variable. For independent variable determined by students' concept mastery and students' creative skills and for the dependent variable is the role-play itself. The instrument that used is an objective test for measure the students' concept mastery and student's creative skills and rubrics of the creative skills so that the analysis of students' concept mastery can be seen in the result of statistical calculation.

Based on Table 6 shows that the sig. Value is 0.000 ; it means that Ho is rejected and H1 is retained. So that the hypothesis that employs is "There are significant differences for students' concept mastery at roleplay in learning the human circulatory system." It can be concluded that the experiment class, which is implemented the role-play has different knowledge in learning the human circulatory system.

The study gives the result that the gain score is experiment class and control class is 47.17, and 24.34 respectively could be seen in Table 2 that means the experiment class has a better result than control class regarding measure about students' concept mastery in learning the human circulatory system. So that the implementation of the role play in determining human circulatory system is more effective than the group discussing class.

Based on the expert activity that conducts during the learning process should be interactive to improve students' concept mastery. The role-play is used as a learning method to help teachers shows the students' understanding of their concept mastery in a particular subject matter. And we could see from the result data that role play is a success, and it indicates that the implementation of role-play has impact improving the cognitive aspect of students' concept mastery (Nurkencana, 2005).
Table 7 Summary of creative skills in the process

\begin{tabular}{|c|c|c|c|c|c|}
\hline \multicolumn{5}{|c|}{ The Result of creative skill in the process } & Total \\
\hline Criteria & 1 & 2 & 3 & 4 & $\begin{array}{l}\text { Score } \\
\text { Affective }\end{array}$ \\
\hline Score & 50 & 40 & 43 & 49 & 230 \\
\hline$\%$ & 79.4 & 63.5 & 68.3 & 77.8 & 72.25 \\
\hline Categories & High & Medium & Medium & High & High \\
\hline
\end{tabular}

Notes:

$1=$ Dare to take a risk; $2=$ Feel the challenge; $3=$ Curiosity and $4=$ Imagination

In students' concept mastery, role-play is one of the methods in teaching-learning process which can interpreted to implement the plan that prepare to achieve the learning objectives in the form of concrete activities and practical teaching, because teaching is an ability that needs to be owned by a teacher in presenting the material lessons to their students (Craciun, 2010). It already is proven based on Nurkencana, (2005) said that the implementation of role-playing could improve students' cognitive aspect that can be noticed by processing the difference between pretest and posttest.

For calculating the statistical data use the score of pretest and posttest in experiment class and control class. Besides that to hypothesis test using the gain score from the range of pretest and posttest score in both courses in that attach on the appendix. All of the result shown the positive effect and the effectiveness of the implementation of the roleplay to improve students' understanding or concept mastery in the human circulatory system.

\subsection{Students' Creative Skills}

This research will measure creative skills with the element that included in creative talent such as creative skill in-process and creative skill in a product based on the model or creative ability, cognitive aspect included in product of creative skills while affective and psychomotor dimension included in creative skills as the product. These result of creative skills process and product that would explain the data set based on the research will describe as following:

\section{Creative Skills in Process}

The data result from creative skills in the process can be taken from the observation sheet and video made of implementation role play as a teaching-learning process. The data in the result of learning about creative skills in operation that can be seen in Table 7.

Based on Table 7 described the result of criteria in the process of creative skills. A criterion number one dares to take risk has score 50 with percentage is $79.4 \%$, and categories of creative ability are high. The second criteria or the criteria to feel the challenge with score 40 and the percentage $63.5 \%$ resulted in the ordinary creative skills. The third criteria, which is curiosity with a number score 


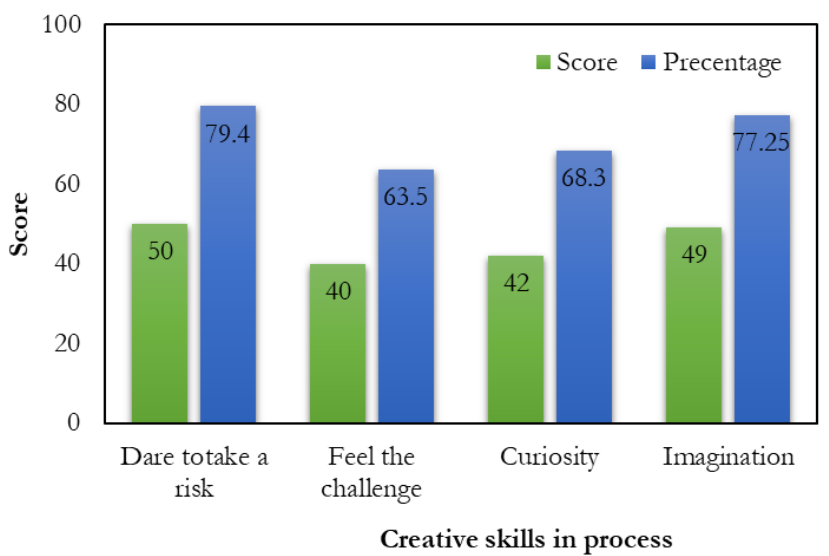

Figure 3 Comparison creative skills in process

of 43 and the percentage $68.3 \%$ occurred in the average creative skills. For the last tests, the forth, which is the students' imagination got the score 49 , and $77.8 \%$ and the category of the creative skill is high. Based on the data, the total valid score is 230 as the process of creative talents as the process is high - the comparison of creative skills in operation that can be seen in Figure 3.

Based on Figure 3 about that can be seen the creative skills in the process that dare to take a risk has the higher score which is 50 with percentage $79.4 \%$ rather than other criteria as creative skills in the process while feeling the challenge is the smallest score which is 40 with the percentage of $63.5 \%$. In the middle position, curiosity has 42 ratings with the rate 68.3 and imagination with score 49 that the percentage of $77.25 \%$.

\section{Creative Skills in Product}

The data result from creative skills in the product could be taken from the rubric of creative ability in the product. The data in the result of creative talents in the product that can be seen in Table 8 .

Table 8 described the criteria of creative skill in the product such as completeness score with an average 7.3 from the maximum rating is 9, with percentage is $81.1 \%$. Thus, the requirements of completeness score category are high. Average of content accuracy (fluency) score is 7.3 from the maximum score is 9 , with percentage is $81.1 \%$, so the category is also high. Average of label, organization (flexibility) score is 6.3 from 9, with percentage is $70 \%$, and it means the category is medium. Average of step (elaboration) score is six from maximum score 9, with percentage of $66.7 \%$ the category is medium. Average of

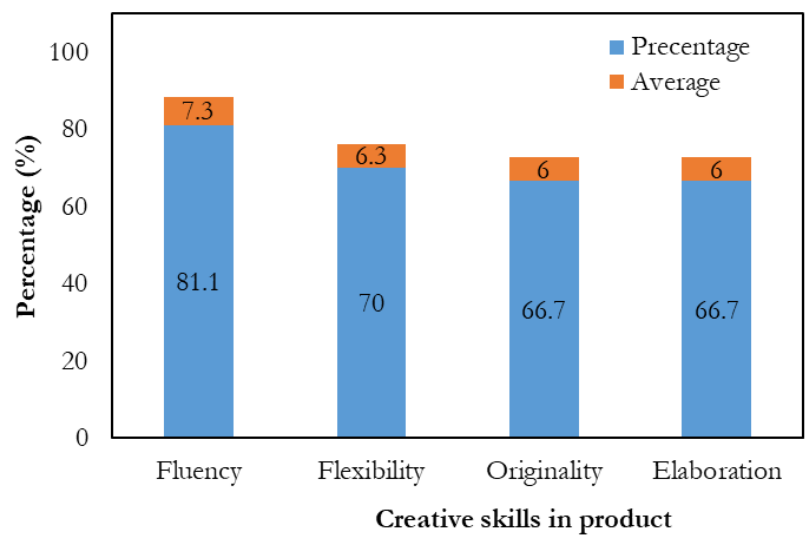

Figure 4 Comparison of creative skills in product

relevancy is 6 over 9 with the percentage of $66.7 \%$ and the category is medium. Average of effectiveness (originality) score is $81.1 \%$ and the category is high. Average of communication score is 6.3 from 9 with the percentage of $70 \%$ and the category is medium. Average of science content dialog score is 6.3 from maximum score is 9 and the percentage of $70 \%$ categorized as medium. The last one is the average of time, effort and energy score is 7.6 over 9 with $84.4 \%$ as the percentage and the category is high. Thus, total score of creative skill in product is 68.4 from the maximum score of 90 with the percentage of $76 \%$ those mean the category is high.

The product of creative skills based on MijaresColmenares, Masten, \& Underwood (1993) is fluency, flexibility, originality, and elaboration so the result will be showed on Figure 4. The product of creative skills such as criteria of fluency has 7.3 with percentage is $81.1 \%$ and flexibility 6.3 with percentage of $70 \%$. Thus, indicated that criteria of fluency greater rather than the criteria of flexibility. While for the requirements of originality and elaboration based on Figure 4. have the same value the average is 6 from the maximum score is 9, with the percentage is $66.7 \%$.

\subsection{The Correlation of Students' Concept Mastery and Students' Creative Skills}

Tanner (2012) stated that the correlation could be defined as the strength of the relationship between two variables; for this research, those are students' concept mastery and students' creative skills. As the previous explanation that each group has posttest score can be analyzed based on the group result got individually. The

Table 8 Summary of creative skill product

\begin{tabular}{|c|c|c|c|c|c|c|c|c|c|c|c|}
\hline Component & Creat & e Skil & in Produ & & & & & & & & Total \\
\hline Criteria & 1 & 2 & 3 & 4 & 5 & 6 & 7 & 8 & 9 & 10 & 68.4 \\
\hline Average & 7.3 & 7.3 & 6.3 & 6 & 6 & 8 & 7.3 & 6.3 & 6.3 & 7.6 & \\
\hline$\%$ & 81.1 & 81.1 & 70 & 66.7 & 66.7 & 88.9 & 81.1 & 70 & 70 & 84.4 & 76 \\
\hline Categories & High & High & Medium & Medium & Medium & $\begin{array}{l}\text { Very } \\
\text { High }\end{array}$ & High & Medium & Medium & High & High \\
\hline
\end{tabular}


analysis is calculation the average of posttest score in one group presentation score got by their performance.

Based on the data can be seen the range of mean in experiment class on pretest is 32.17 and posttest shown the score is 79.50 while in control class the pretest is 38.67 and posttest is shown the score is 64.00 . Those are taught that in the pretest of experiment class lower than the control class but the posttest, the experiment class is higher than the control class. From the result of calculation statically, the difference between the pretest and the posttest is stated by gain score $(G)$ as much as 47.17 in experiment class and 24.34 in the control class. Means that the effect of students' concept mastery in experiment class is better than the control class shown by the increasing score.

Based on Figure 3 about that can be seen the comparison creative skills in the process that dare to take a risk has the higher score which is 50 with percentage $79.4 \%$ rather than other criteria as creative skills in the process while feeling the challenge is the smallest score which is 40 with the percentage of $63.5 \%$. In the middle position, curiosity has 42 score with the percentage 68.3 and imagination with score 49 that the percentage of $77.25 \%$.

Based on Figure 4 shows that the product of creative skills such as criteria of fluency has 7.3 with percentage is $81.1 \%$ and flexibility 6.3 with a percentage of $70 \%$. Thus, it indicated that standards of fluency greater rather than the criteria of flexibility. While for the criteria of originality and elaboration based on Figure 4. have the same value, the average is six from the maximum score is 9 with the percentage is $66.7 \%$.

Those results mean that the implementation of the role play in learning the human circulatory system is effective as the learning method. the product created by the students, the cognitive level is C6 (Creating) that expressed in scenario design as the product. means that inside the product must conduct the concept of the human circulatory system that related to their understanding. Based on the definition of creativity is something that must be applied approximately to a task and must utilize the form of media as a vehicle of communication, which is completely aligned with the Revised Bloom Taxonomy. Bloom's Taxonomy puts creating at the top level of higherorder thinking because of the nature of the thinking involved in the creative process, which requires students to move beyond basic understanding. This makes sure that there is a correlation between students' concept mastery and students' creative skills.

According to the data result we could compare that the experiment class got a higher score than the control class, it makes the experiment class was success to prove that the implementation of role-play could give an effect to the students' concept mastery and creative skills than the control class that only did the ordinary group discussion instead of implementing the role play like the experiment class did and it is supported by what Freire, Baptista, \&
Freire (2016) said that the role play influenced students' achievement in score that the achievement here means students' concept mastery based on the cognitive domain.

While the creative skills from both students could be seen by the result of the data of the experiment class and those results, show the percentage from each category that the students did the role play well and triggered them to be more creative. The control class one could not do the same way because by doing the ordinary group discussion, they were not getting an equal chance to be more creative. The flexibility and the opportunity to communicate their idea is limited by the ideas compare to the experiment class, which implemented the role-play; they free to move during the learning process. They even made their design by themselves by making the scenario of the human circulatory system before they do the role-play in front of the class.

The role play indeed could effectively develop students' creative skills (Agustin, Liliasari, Sinaga, \& Rochintaniawati, 2017) it is proved also based on this study about the effect of role-playing not only on students' concept mastery but also students' creative skills in learning the human circulatory system.

\section{CONCLUSION}

The research about the effect of role-playing on students' concept mastery and students' creative skills in learning the human circulatory system has been conducted systematically. According to the result of research, those are the conclusions for this study as follow (1) The implementation of role-playing in learning the human circulatory system is effective in increasing the students' concept mastery. The results got from the average of the $\mathrm{N}$-Gain that conducted in the experiment class, which is 0.7 , and the control class is 0.4 . The result showed that the $\mathrm{N}$-Gain in the experiment class is higher than the control class categorized whether it is as medium or high, the result also indicated by the mean of the experiment class is higher than control class which is $79.0>64.00$ respectively. The improvement of students' concept mastery supported by the acceptance of the $\mathrm{H} 1$ so that the $\mathrm{H} 0$ is rejected.it means that there is a significant effect of the implantation of the role play on students' concept mastery. (2) Students' creative skills toward the role play in learning the human circulatory system are effective to increase the creative abilities and give the improvement of current aspect in creative skills dimension. The result of percentage in experiment class that implementing the role play is higher than the control class which is only the classic group discussion. (3) The result of the research inlined with others researches which study the same variable that found there is an effect about implementing the role play. Not only on students' concept mastery and students' creative skill, but also the role-play could influence the students' enthusiasm and triggering students being more interesting (Prima, 
Putri, \& Sudargo, 2017). Obviously, students can more actively participate during the learning process compared by the experiment class and the control class activity observed during the learning process.

\section{ACKNOWLEDGMENT}

Author's wishing to acknowledge the principal of the school for the permission to conduct the research (teaching in the class for several meetings).

\section{REFERENCES}

Agustin, R. R., Liliasari, L., Sinaga, P., \& Rochintaniawati, D. (2017). Preservice Science Teachers (PSTs)' Creative Thinking Skills on Atoms, Ions and Molecules Digital Media Creation. Journal of Physics: Conference Series, 895(1), 012114.

Anderson, L. W. (2001). A Taxonomy for Learning, Teaching and Asessing: A revision of Bloom's Taxonomy of Educatinal Objectives. New York: Longman.

Anderson, L. W., \& Krathwohl, D. R. (2001). A taxonomy for Learning, Teacbing and Asessing: A Revision of Bloom's Taxonomy of Educational Objectives. Boston: Pearson Education Group.

Azra, A. (2002). Paradigma Baru Pendidikan Nasional: Rekonstruksi dan Demokrasi. Jakarta: Kompas,

Bjork, C. (2005).Indonesian Education: Teachers, Schools and Central Bureaucracy. New York and London: Routledge.

Craciun, D. (2010). Role-playing as a creative method in science education. Journal of Science and Arts, 10(1), 175.

Creswell, J. W. (2012). Educational Research: Planning, Conducting and Evaluating Quantitative Research, 4th Ed. Boston: Pearson.

Daniau, S. (2016). The Transformative Potential of Role-Playing Games-: From Play Skills to Human Skills. Simulation \& Gaming, 47(4), 423-444.
Edmiston, B, \& Wilhem, J.D. (1998) Repositioning views/ review positions. In B J. Wagner (Ed). Educational drama and language arts: What research shows (pp. 90-117). Chicago, IL: Heinamann.

Freire, S., Baptista, M., \& Freire, A. (2016). Sustainability and Science Learning: Perceptions from 8th Grade Students Involved with a Role Playing Activity. Universal Journal of Educational Research, 4(8), $1757-1763$.

McSharry, G., \& Jones, S. (2000). Role-Play in Science Teaching and Learning. School Science Review, 82(298), 73-82.

Mijares-Colmenares, B. E., Masten, W. G., \& Underwood, J. R. (1993). Effects of trait anxiety and the Scamper technique on creative thinking of intellectually gifted students. Psychological reports, 72(3), 907-912.

Nurkencana. (2005). Evaluasi Hasil Belajar Mengajar . Surabaya: Usaha NAsional.

Önkal, D., Sayım, K. Z., \& Lawrence, M. (2012). Wisdom of group forecasts: Does role-playing play a role?. Omega, 40(6), 693-702.

Prima, E. C., Putri, A. R., \& Rustaman, N. (2018). Learning Solar System Using PhET Simulation to Improve Students' Understanding and Motivation. Journal of Science Learning, 1(2), 60-70.

Prima, E. C., Putri, C. L., \& Sudargo, F. (2017). Applying Pre and Post Role-Plays supported by Stellarium Virtual Observatory to Improve Students' Understanding on Learning Solar System. Journal of Science Learning, 1(1), 1-7.

Rumore, D., Schenk, T., \& Susskind, L. (2016). Role-play Simulations for Climate Change Adaptation Education and Engagement. Nature Climate Change, 6(8), 745.

Stevens, R. (2015). Role-play and Student Engagement: Reflections from The Classroom. Teaching in Higher Education, 20(5), 481-492.

Tanner, D. (2012). Using Statistics to Make Educational Deciscions. Los Angles: SAGE Publications Inc.

Yasin, A. I., Prima, E. C., \& Sholihin, H. (2018). Learning Electricity using Arduino-Android based Game to Improve STEM Literacy. Journal of Science Learning, 1(3), 77-94. 